\title{
伊豆半島及びその周辺海域の地震活動 にみられる非重曽性と移動性
}

\author{
気象研究所吉 田 明夫
}

(昭和 59 年 12 月 24 日受理)

\begin{abstract}
"Non-superpositionality" and "Migrationality" Observed in the Seismic Activities in and around the Izu Peninsula
\end{abstract}

\author{
Akio YosHIDA \\ Meteorological Research Institute \\ (Received December 24, 1984)
}

\begin{abstract}
Seismic activities in and around the Izu Peninsula during the period from 1926 through 1982 are investigated. In this sea region earthquakes are apt to occur in the shallow areas, and some earthquake swarms seem to be related to volcanism. Several "seismic gaps" are recognized in this region, and the possibility of earthquake occurrence in the "gap" observed at the Oiso hills, the north-west coast of Sagami Bay, is examined with reference to the location of active faults, crustal movements during the Quaternary, and historical data of earthquakes as well. The most conspicuous features in space-time distributions of earthquakes in and around the Izu Peninsula are "non-superpositionality" and "migrationality". Succesive active regions do not overlap each other and have a tendency to move to adjacent areas. The meaning which these characteristics suggest on seismogenesis is preliminarily discussed.
\end{abstract}

\section{§1. はじめに}

伊豆半島周辺域では 1974 年に $M 6.9$ の伊豆半島沖地震が発生して以来, 1978 年に $M 7.0$ の伊豆大島近海地震, 1980 年には $M 6.7$ の伊豆半島東方沖地震と, 相次いで $M 7$ クラスの 地震が発生し，また三宅島から伊豆大島, 川奈崎沖にかけての海域では活発な群発地震活動が 繰り返されている。 このような近年の地震活動に加えて, 北緯 $35^{\circ} 00^{\prime}$ から $35^{\circ} 20^{\prime}$ にかけての 地域にみられる「空白域」は, 力武 (1980), 茂木 (1981), 吉田 (1982) 等によつて指摘され た地震活動の北上傾向とあいまつて, 将来, 地震発生の可能性が考えられるところとして注目 を集めている.

ここでは 1926 年以降における地震活動のいくつかの特徽を, 気象庁地震月報の資料を基に 考察する. 数十年間という期間は地震活動の一サイクルをみるには十分とはいえない. 特に,

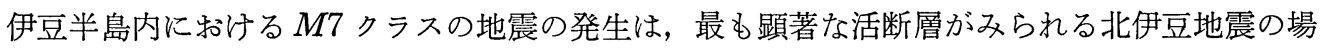
合でも, 約 1000 年の間隔を有すると考えられている [久野 (1962)] から, 数十年の地震活動 
というのは, そのごく一部をみるにすぎない,しかし, この周辺海域に扣いては, 近年, 群発 地震活動や火山噴火が繰り返し起きて括り, それら一連の活動の相互の関連, また $M .7$ クラ スの地震発生との関係がどのようになつているかは興味をひく問題である.

$\S 2$ で，まず地震活動の全般的な特徵について概観したあと， §3 では上述のような観点から， それぞれの活動のシーケンスと相互の関係を調べる.ここで特に注目するのは, 地震活動の非 重畳性と移動性である. このような性質は, 広域に作用している応力場の中で, 単に弱いとこ ろが破壊を起こすのが地震であるとする考方方とは合致しない。サイスモジェネシスに拈ける， こうした特徴のもつ意味については最後の §5 で議論する. そして 84 では, 相模湾北西沿 岸部にみられる「空白域」について, 地殼变動や歴史地震の面から地震発生の可能性を検討す る.

\section{§2. 近年の地震活動のいくつかの特徵}

Fig. 1, Fig. 2 はとれぞれ, 1926 年から 1960 年末でと, 1961 年から 1982 年までの, 伊 豆半島和よびその周辺海域に打ける

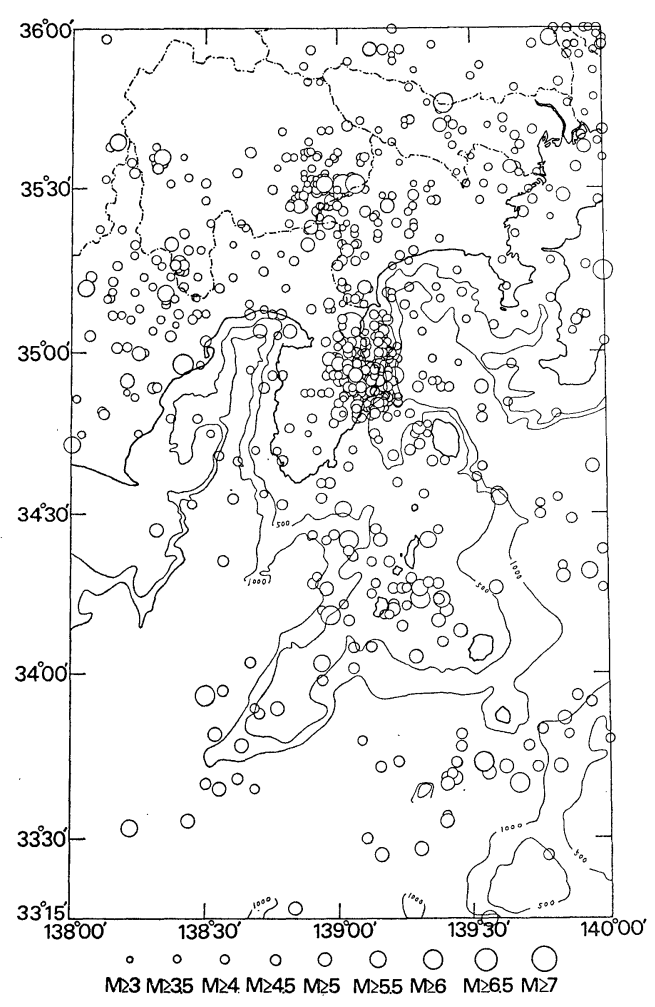

Fig. 1. Epicenters of earthquakes in the period from 1926 through $1960 ; M \geqq 3.0$, hypocenter depth $\leqq 40 \mathrm{~km}$. Data are after the Seismological Agency, Supplementary Volume No. 6.
$M 3.0$ 以上, 深さ $40 \mathrm{~km}$ 以浅の地震 の震央をプロットしたものである（た だし，1982 年 12 月 27 日から始まつ た三宅島近海の群発地震を除く). Fig. 1 の資料は地震月報別冊第 6 号 を用い，また Fig. 2 は地震月報によ つている. そして Fig. 3 は, これら を合わせた 1926 年から 1982 年まで の地震活動を表わす。

1960 年以前に和いては，特に伊豆 半島南方海域に和注震源の精度は, それ以後と比べて相対的に低いと考光 られるけれども, これらの図から, 海 域に和いては $1000 \mathrm{~m}$ 等深線の内部, すなわち浅いところで地震が多く発生 していることがわかる.これについて はすでに, 1961 年以降の $M 4.0$ 以上 の地震について調べた吉田（1982）が 指摘しているが，Fig. 3 はもつと長 期にわたつて， $M 3.0$ 程度以上の地 震についてもそらした特徴があること を示している. 浅い海域の基盤には火 山岩が分布している[海上保安庁水路 部 (1979) ] といらことから，このよう な特徵は, 伊豆半島周辺海域の地震活 
動が，間接的なものも含めてなんらか の火山活動に関連していることを示し ているともみられる[吉田 (1982)] が， しかし，これを実証するには，更に， 個々の地震活動の特性, 地震のメカニ ズム，地殼構造等，様々な面から検討 する必要があろう。な拉，田中(1984) は, 三宅島の噴火と周辺の地震活動と の関係について詳細な考察を行なつて いる.

牧 (1983) は, 南関東地域の地震活 動が東経 139 度線に沿つて活発である と述べ，かつその周辺でいくつかの空 白域が存在することを指摘した. Fig. 3 をみると，周辺の活動に比べて抜け ているところとして，例えば，伊豆下 田付近からその南東方向にかけての海 域, 伊豆半島北西部から静岡県北東部 （神奈川県境）にかけての地域, 神奈 川県北西部之東京都の境界域，それに 規模は少し小さいが相模湾北西沿岸の 大磯丘陵付近があげられる。このらち 前二者については牧 (1983) 女指摘し ている.ただし，これらの地震「空白 域」は, 1926 年以降比較的大つぶの地 震が発生していないところということ であつて，これが前兆現象としての地

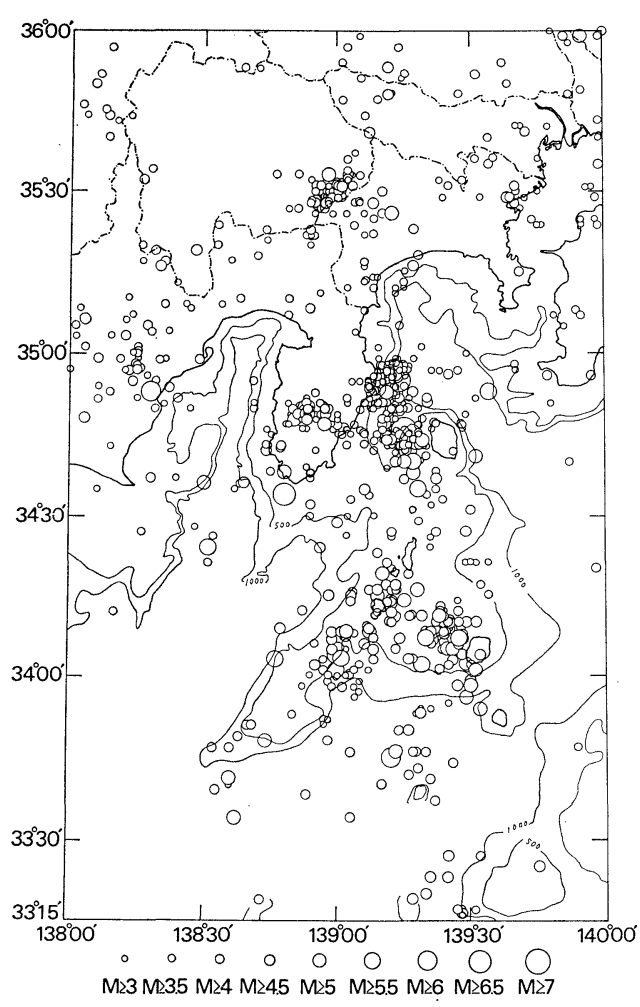

Fig. 2. Epicenters of earthquakes in the period from 1961 through 1982; $M \geqq 3.0$, hypocenter depth $\leqq 40 \mathrm{~km}$. (The swarm activity near Miyakejima island which started on Dec. 27, 1982 is not contained.) Data are after the Seismological Bulletin of the Japan Meteorological Agency.

震活動の低下一いわゆる第二種空白域 [MOGI (1979)] を表わすのかどうかについては，そ れ以前の活動の経過も知る必要があり，これだけではなんともいえない.

MOGI (1979) は, 近年, 伊豆半島地域の地震活動が北上する傾向をみせて北緯 35 度線付近 まであがつてきていることや, そのすぐ北側, 相模湾北西部には, 最近, 微小地震のドーナッ ツ・パターンがみられること, またこの海域には南北に走る断層があつて, 1980 年の地震断層 はその南半分に相当していること等の事実をもとに，この地域で次の大きな地震が発生する可 能性が考えられるかもしれないと述べている. Fig. 1 をみると, ここは1930 年の北伊豆地震 に伴なら一連の活動によつてかなり埋められているようにもみえるが，1961 年以後 (Fig. 2) は, この地域とその南側との地震活動の差は顕著であり, 確かに注目すべき場所であることに は違いない，ただ一方，§3 で示すように，近年の伊豆半島周辺域の新しい地震活動は，それ 以前「空白」だつたところを次々と埋めていくような傾向がある.こうした観点からは，先に あげたいくつかの「空白域」も，いわば「中小規模の局所的な地震活動に関する第 1 種の空白 


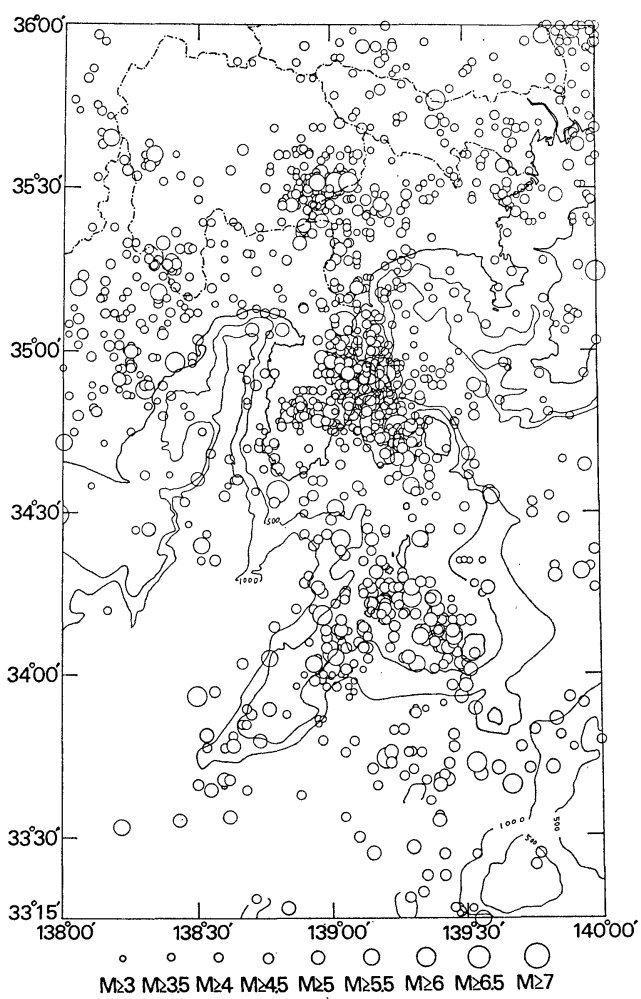

Fig. 3. Epicenters of earthquakes in the period from 1926 through 1982, being a combination of Fig. 1 and Fig. 2. It is noticeable that earthquakes in the sea region occur largely in the shallow area.
域」ともいうべき意味合いで一応注意 すべき場所であるといえよう. 大磯丘 陵付近にみられる「空白域」について は §4 で更に詳しく検討する.

な拉，静岡・神奈川県境から伊豆半 島を縦断して松崎付近に拔ける弧を境 にして，その東側では活発な地震活動 がみられるのに，西側では著しく静か である.このラインについては, 吉田 ・他 (1979) が，伊豆半島の変形を伴 なら構造線の存在を考光, 中野・他 (1980) がテクトニック応力場の境界 線を想定しているほか，また星野・小 出 (1984) も，泳涪同椂なところに地 質構造の不連続線があると述べている. 伊豆半島北西部から静岡県北東部（神 奈川県境）にかけてみられる地震空白 帯は,こらしたテクトニクスとの関連 でとらえるべきかもしれない。

伊豆半島南端から駿河湾を北西方向 に横切つて分布する地震は, 茂木 (1979), 吉田 (1983), 吉田・他 (1984) のいう活構造線に関係したものとみる ことができよう。

\section{§3．地震活動の非重畳性と移動性}

1974 年伊豆半島沖地震のあと, 伊豆半島周辺域では $M 7$ クラスの地震が続発し, また海域 では群発地震が繰り返し発生している。これらの地震活動についてはすでに数觉切れない漂ど の研究が発表されているので，ここではそうした個々の活動についてはふれず，むしろそれら 相互の間の関係について着目する.

Fig. 4 は，1974 年伊豆半島沖地震とその余震を白丸で，また 1978 年伊豆大島近海地震と その前震・余震を黒丸でプロットしたものである [山川・他 (1979)]. 1978 年伊豆大島近海地 震のあと，余震活動は伊豆半島内に及んだが，Fig. 4 をみると，その活動域は 1974 年伊豆半 島沖地震の余震活動域とは重なつていないことがみてとれる。こうした傾向は，他の隣接した 地震活動の間でも認められ，例光ば，Fig. 5 は，1978 年伊豆大島近海地震の前震・余震を白 丸で，1980 年伊豆半島東方沖地震の 前震・余震を黒丸でプロットしたものであるが，この場 合も両者の活動域は互に重なつていない。また 1980 年伊豆半島東方沖地震の前後, この近辺 ではくり返し群発地震活動があつたが， $M 5.4$ の地震を含む 1978 年 11 月 12 月の活動域 は，M6.7 の地震が発生した 1980 年 6 月〜 7 月のそれとは少しずれている [茂木 (1981)]. 
ただし， 1980 年伊豆半島東方沖地震 の震央付近はその後もひき続き地震活 動が活発で, これはこの地点の特異性, すなわち地下の何らかの火山活動との 関連性を表わしているものと思われる. 地震のメカニズムをみても, この地域 のテクトニックな応力場を反映してい ると考兄られる北西一南東方向に最大 主圧力軸をもつ横ずれ断層的なもの以 外に，正断層的な解もかなりの割合で 存在して特り [井元・他 (1981); 吉 田・他 (1980) ], このことも活動域の コンパクト性とともに火山活動の関与 を示唆する。な挍，SEGAWA (1983)， ISHIDA (1984) はそれぞれ，1980 年の 活動が群発地震と本震余震系列の二つ のタイプの活動の重ね合わせであつた という見方を提出している.

Fig. 6 は, 1974 年伊豆半島沖地震 の余震分布と, それ以前の 35 年間の

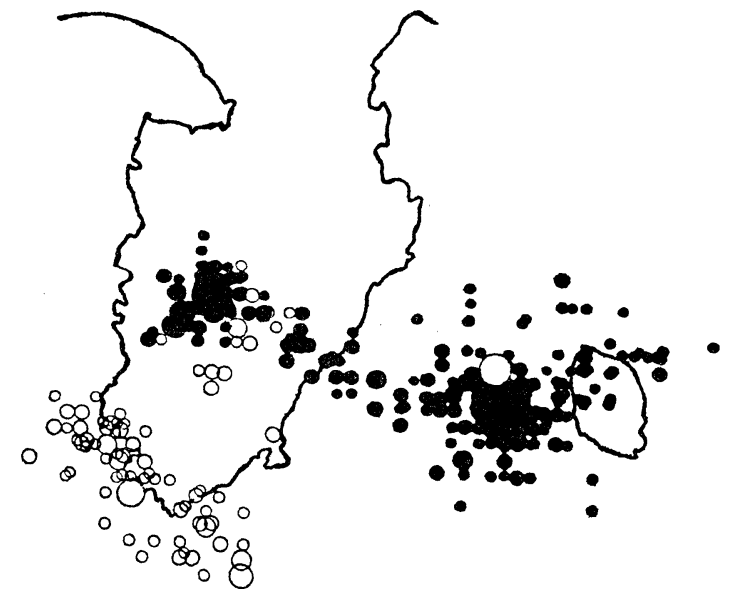

Fig. 4. Foreshocks of the 1978 Izu-OshimaKinkai earthquake (solid circles), and aftershocks of the 1974 Izu-Hanto-Oki earthquake (open circles). It is recognized that aftershock areas of the two earthquakes in the central Izu Peninsula do not overlap. [after YAMAKAWA et al. (1979].

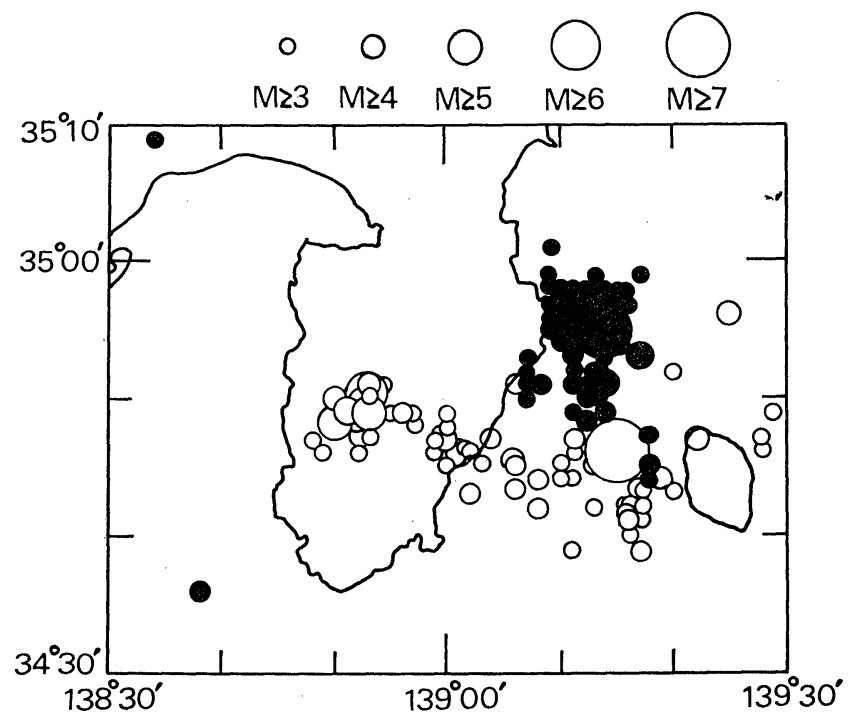

Fig. 5. Open circles represent foreshocks and aftershocks of the 1978 IzuOshima-Kinkai earthquake (Jan. 14, 1978-Nov. 25, 1978) and solid circles show those of the 1980 Izu-Hanto-Toho-Oki earthquake (Jun. 25, 1980Dec. 31, 1980). The two seismic regions do not overlap. 


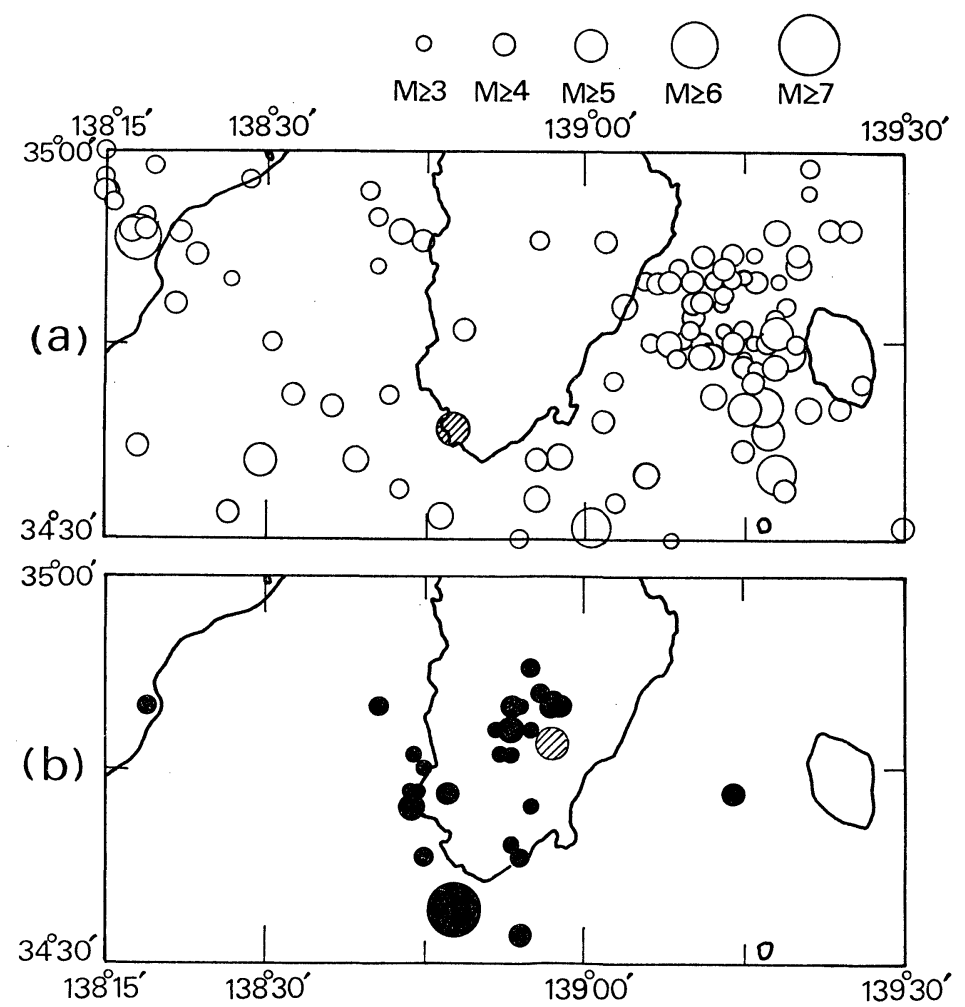

Fig. 6. (a) Epicenters of earthquakes in the period from Jan. 1, 1939 through May 9, 1974, before the occurrence of the 1974 Izu-Hanto-Oki earthquake. The slashed circle represents the M5.4 shock on Nov. 3, 1964 which may be a foreshock of the 1974 event.

(b) Aftershocks of the 1974 Izu-Hanto-Oki earthquake (May 9, 1974-Dec. 31, 1974). It seems that these shocks fill the "seismic gap" seen in Fig. (a). The slashed circle represents the $M 5.4$ shock on Aug. 18, 1976, which also occurred in the "gap".

地震分布を示したものである。この場合も，1974 年の活動はそれまでの空白域を埋めるょう な形で生じている. Fig. 6(a) の中で斜線を引いた丸は 1964 年 11 月 3 日に発生した $M 5.4$ の地震で，これは 1974 年伊豆半島沖地震の広義の前震ともみなされるものである. また Fig. 6(b) の中の斜線をひいた丸は 1976 年 8 月 18 日の $M 5.4$ の地震で, これは 1978 年伊豆大 島近海地震の伊豆半島内にのびた断層の近くで発生しているが，Fig. 5 をみると，この付近で は大粒の余震はあまり起きていないよらにみえる.

このような地震活動域の非重畳性といら特徵は, 更に, 三宅島周辺の地震活動についても認 められる. 三宅島付近では 1982 年 12 月から 1983 年 1 月にかけて $M 6.4$ の地震を含む活 発な群発地震活動があり, また 1983 年 10 月には三宅島火山が 22 年ぶりに噴火したほか, それに伴なつて再び $M 6.2$ の地震を最大とする群発地震活動があつた. Fig. 7 は, 1961 年 から 1982 年 12 月 26 日までの地震を黒丸で, 1982 年 12 月 27 日から 1983 年 1 月 31 日 


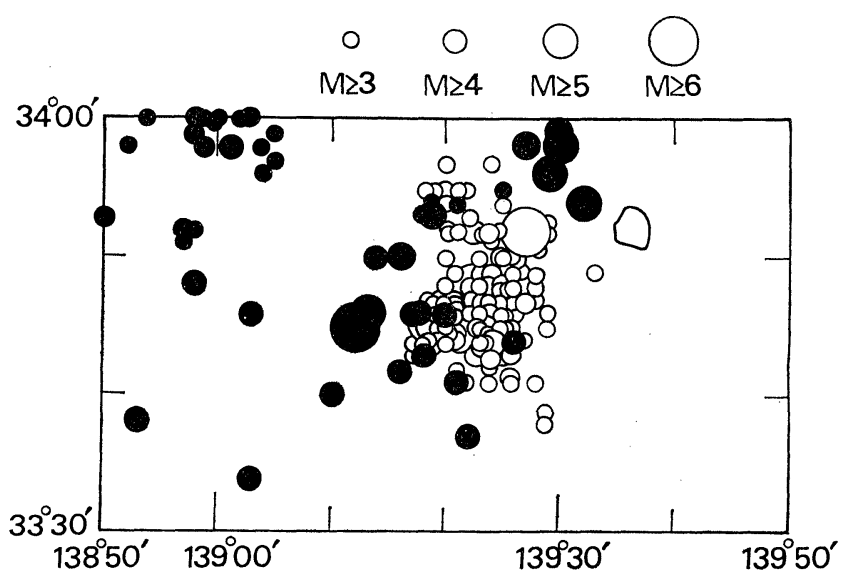

Fig. 7. Epicentral locations of earthquakes near Miyakejima island in the period from Jan. 1, 1961 through Dec. 26, 1982 (solid circles), and those of the swarm activity in Dec. 1982 including $M 6.4$ shock on Dec. 28 (open circles). It is recognized that the latter activity fills a "gap" in the preceding activity.

までの群発地震活動を白丸でプロット したものであるが，この場合も先に述 ベた例と同様な特徵のあることがみて とれよう. 同じくFig. 8 は, 1982 年 12 月から 1983 年 1 月にかけての活動 と, 1983 年 10 月の群発地震活動をプ ロットしたものだが，やはりこれらの 活動は互に重なつていない. しかも, 三宅島噴火を伴なつた 1962 年の地震 活動の領域も，1982 年 12 月から 1983 年 10 月にかけての一連の活動域とは 異なつているようにみえる (Fig. 2). 更に，Fig. 9 は，三宅島西方の地震活 動について，それぞれ期間別に符号を 変えて地震をプロットしたものだが， この場合には，異なる期間の活動は互 に重ならないだけでなく，次第に西方 に移動していつたことがわかる。な特， 三宅島周辺海域では 1960 年以前にも かなりの規模の活動を繰り返したこと が知られているが，震源精度の問題か ら，それらの個々の活動域の広がりと

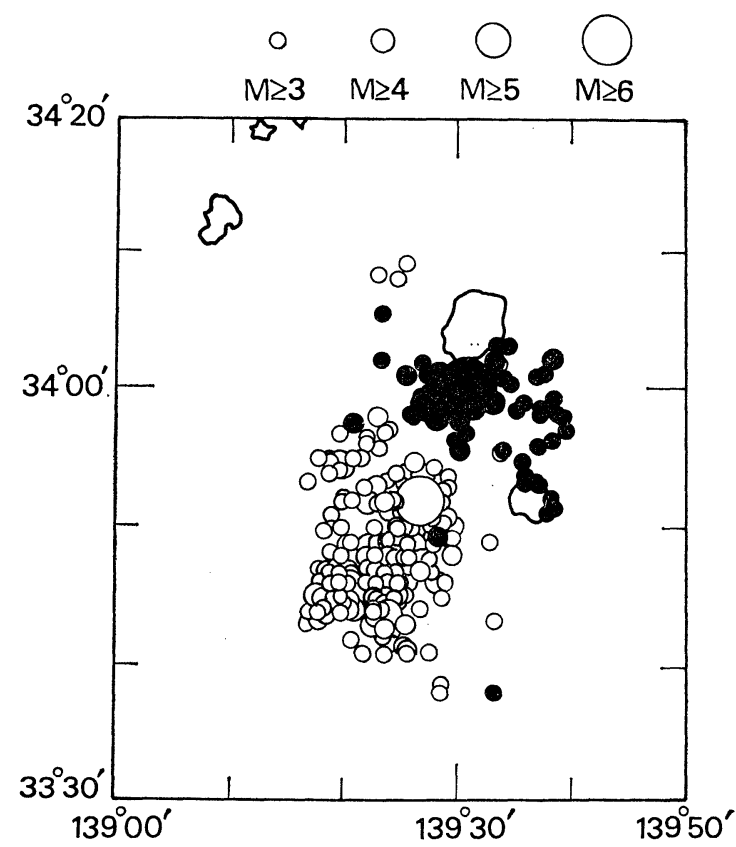

Fig. 8. Two swarm activities near Miyakejima island. Open circles represent shocks in the period from Dec. 27, 1982 through Jun. 30, 1983, and solid circles show events in Oct. 1983. It is clear that the two active regions do not overlap. 


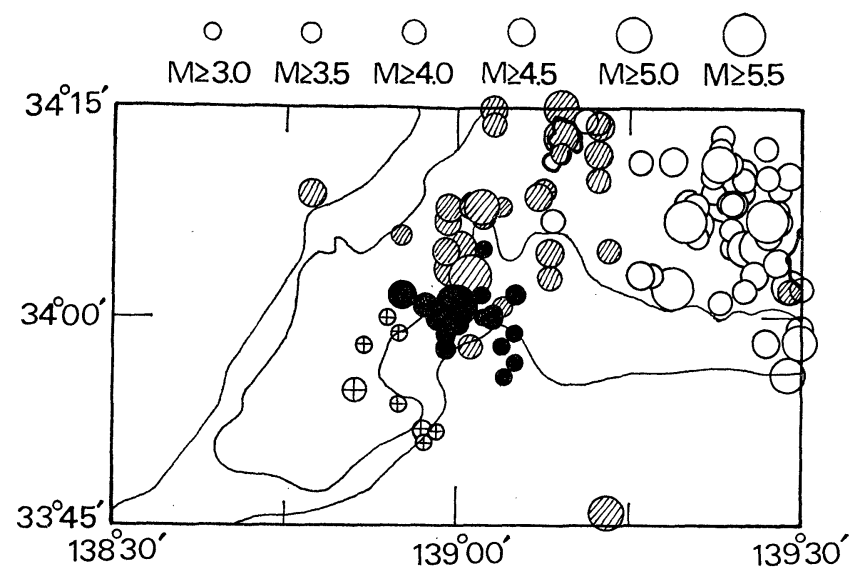

Fig. 9. Seismic activities in the west region of Miyakejima island. Open circles, slashed circles, solid circles and crossed circles represent shocks in the period, Jan. 1, 1961-Dec. 31, 1962, Jul. 1, 1965-Jun. 31, 1967, Sep. 1, 1980-Oct. 31, 1980 and Jan. 1, 1981-Jan. 31, 1981, respectively. It is seen that the activities of each period not only did not overlap but also moved to the west successively.

相互の関係を議論することは現在の資料では困難である.

\section{§4. 相模湾北西沿岸部の「空白域」}

ここでは先にあげたいくつかの「空白域」のらち, 将来地震が発生する可能性の考えられる ところとして, 特に, 相模湾北西沿岸の大磯丘陵付近にみられる空白域について検討する.

Fig. 10a は, 1926 年から 1960 年すでの $M 3.0$ 以上, 深さ $40 \mathrm{~km}$ 以浅の地震をプロット したものであり, Fig. 10b は同じく 1961 年から 1982 年まで, そして Fig. 10c はこれらを 合せた 1926 年から 1982 年までの地震をプロットしたものである.これらの図には地形も描 き入れてある. Fig. 10b をみると，ちようど大磯丘陵をその中に含んできれいなりング状の パターンが存在するが, Fig. 10c から，ここは 1926 年にさかのぼつて地震が少なく，特に， 1927 年 $M 4.4$ の地震（斜線をひいた丸）と 1939 年の $M 3.9$ (十字印の丸）の地震を除くと, $M 3.0$ 以上の地震に関する限り全くの空白となる.

大磯丘陵は西縁を A 級の活断層である国府津一松田断層で限られた隆起地塊で, 北側には渋 沢断層, そして東側には伊勢原断層が存在する。これらの断層の地質学的最近の活動度は大さ く，例えば国府津-松田断層が 6300 年間に $22 \mathrm{~m}$ の変位を示している [松島 (1982)] ほか, 伊勢原断層が $5000 \sim 4500$ 年間に $3.5 \mathrm{~m}$ くい違い [今永・他 (1982)] , 渋沢断層も約 $1 \mathrm{~mm} /$ 年の変位速度をもつている [狩野他 (1984) ] . たた, 大磯丘陵南縁の完新世最高位段丘面であ る中村原面の高度は海抜 $30 \mathrm{~m}$ を越光, その平均隆起速度は $5 \mathrm{~m} / 1000$ 年に達すると見積られ ている[熊木・市川 (1982)；太田他（1981）など]。

一方, 松田 (1977) は, 1923 年関東大地震による地殼上下変動が, 大磯丘陵を中心にした東 西対称的なドーム状のパターンをしていて, 国府津一松田断層沿いのくい違いを生じなかつた 

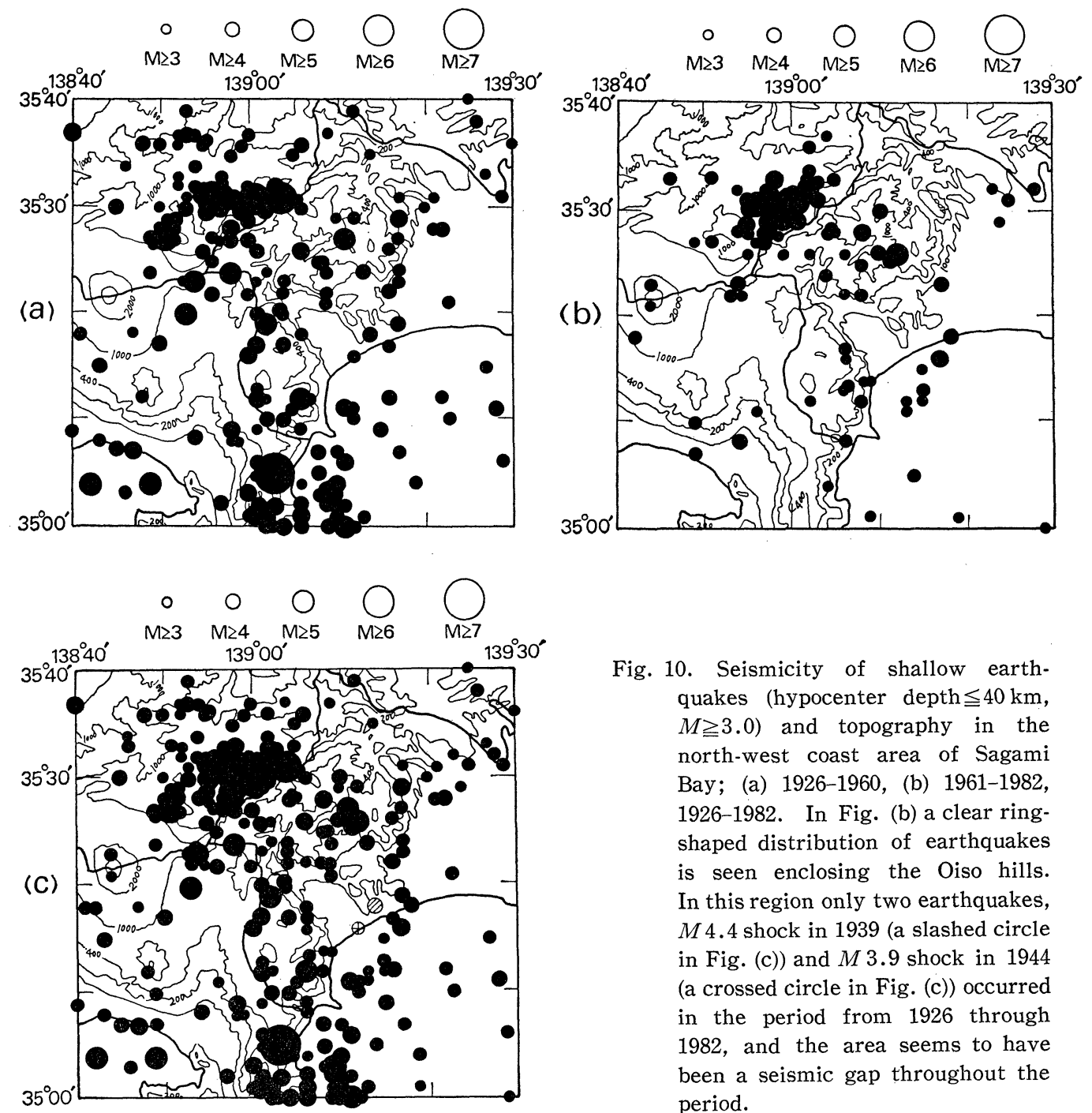

Fig. 10. Seismicity of shallow earthquakes (hypocenter depth $\leqq 40 \mathrm{~km}$, $M \geqq 3.0$ ) and topography in the north-west coast area of Sagami Bay; (a) 1926-1960, (b) 1961-1982, 1926-1982. In Fig. (b) a clear ringshaped distribution of earthquakes is seen enclosing the Oiso hills. In this region only two earthquakes, M4.4 shock in 1939 (a slashed circle in Fig. (c)) and $M 3.9$ shock in 1944 (a crossed circle in Fig. (c)) occurred in the period from 1926 through 1982 , and the area seems to have been a seismic gap throughout the period.

ことから, 国府津一松田断層の断層崖を生じさせるような別のタイプの地震を考える必要があ るとして，その再来周期を 140 年〜330 年と見積つた。また，石橋（1977）も，西相模湾断層 に和いて少なくとも最近 350 年間, 約 $2 \mathrm{~m} / 70$ 年の相対变位が地震によつて解消されていると 推定し, この地域での $M 7$ クラスの地震の発生周期は約 70 年であると述べている. 歴史地 震の記録をみても, 小田原付近で $M 6 \sim 7$ の地震が繰り返し発生していることがわかる [宇佐 美(1980)].

現在，もちろんこれだけの事実で，大磯丘陵付近にみられる「空白域」が来るべき地震の前 兆的なものであるとは断定できない. 例えば「空白」という事実についても, 1926 年以後, こ の「空白域」中に発生した $M 3$ 以上の地震は, 地震月報には確かに 2 個しか記載されていな 
いが，当時の震源決定能力からみて，1930 年代，1940 年代において，M3〜M3.5 の地震が 全く起きなかつたとは必ずしも断定できない。また 1930 年北伊豆地震の余震活動域について む再調査が望まれる. 更に考慮しなければならないことは, この地域一帯が 1923 年関東大地 震の震源域の中に含まれていることである. この時, かなりの規模の余震が神奈川県西部に発 生したことは確かで [宇津 (1979); 宇津 (1981); UTSU (1981)], 問題の「空白域」付近の歪み エネルギーはこれによつて一応解放されたと考えられる. その後 $M 4$ 以上の地震がほとんど 発生していないことはいえても，M3 までとつた時に, 先にも述べたよらにここがいつから静 稳化したかについてなお不確定要素が残る。しかし，このようなことを考慮したらえでもなお， 伊豆半島周辺域の地震活動にみられる非重畳性・移動性と最近の北上傾向, またこの地域の歴 史地震の概周期性, 更には地質学的最近における地款変動の大きさ等を合わせ考えたとき, 伊 豆半島北東部から相模湾北西部を含めたこの「空白域」付近の地震活動の推移については, 今 後注意深く見守つていく必要があるといえよう。

\section{$\S 5$. 議論}

伊豆半島周辺及びその南方海域での地震活動には, これまでみてきたように, 相続く活動域 の非重畺性と，それまで空白だつたところが次第に埋つていくという特徵がある。こうした性 質が震源域の形成においてどのような意味をもつているか試論的に考劣てみる.

まず, しばしばいわれるよらに，もし広域に作用している応力場のもとで, 弱いところが次 々と破壊していくのが地震であるとすると，いつたん地震が発生して断層が生じた部分がある 意味では最も弱いはずだから，その地震発生前と同じ応力場のもとでは，同じところで再び地 震が起きるはずである。しかし実際はとらではない，といらことは，広域に作用している大き なスケールの応力場が直接, ある特定の場所での地震発生をもたらしているのではないという ことを表している．ある場所で破壊が生じるかどうかについては，まさにその近辺の応力場が 重要な役割を果しているのに違いない [YoSHIDA (1979)]。この意味で, 地震が何故発生する かは，一般的には茂木（1966）がつとに指摘しているょうに，地殼が不均一であり，応力場が 非一様であるからといつてよいだろう。また，火山活動域等を除いて，いつたんある地域の応 力場が解放されると，そこで再び破壊が起きるまでには相当の年数を必要とするといらことは， その地震発生にかかわる応力場の形成, もしくは応力場が形成される条件が再び整えられるプ ロセスはゆつくりしたものであることを示している。

伊豆半島周辺域の地震活動にみられるもら一つの特徵は, 活動領域が次第に移動していくと いらことである. 1974 年伊豆半島沖地震以後の地震活動の北上傾向については力武 (1980) に よつて指摘されたが, 茂木 (1981), 吉田 (1982) は, この傾向が 1962 年三宅島近辺の地震活 動にまでさかのぼることを示した. ただしミ3でみたように，局所的には必ずしも一般的に北 上傾向があるというわけではない. 1961 年から 1980 年にかけての三宅島西方の海域では次第 に西に移つている. また 1978 年伊豆大島近海地震の際には, 東西に割れた断層が伊豆半島に 入つて西北西方向に進展し, 更に半島中央部で今度は南西方向に延びている. これは破壊の末 端に拈ける応力場の增大だけでなく, 地体構造やそこでのサイスモジェニックな条件とも関係 しているのであろう.

何故, ある場所に，ある時，ある規模の地震が発生するかを理解するには，テクトニックな 
広域応力場に着目するだけでなく，まさにそこにおける，ある意味では局所的な条件，状況を 明らかにする必要がある．伊豆半島周辺域の地震活動にみられるいくつかの特徵は，それを考 えるらえで一つの手がかりを与えるものと思われる.

\section{謝 辞}

草稿を通読して適切な御教示, コメントを下さつた東京大学地震研究所, 茂木清夫教授に深 く感謝いたします，神奈川県立博物館の今永 勇専門学芸員には重要な文献を教えていただき， また, 山川宜男, 勝又 護両博士との常日頃の議論は, 著者の考えをすつきりさせるらえでた いへん有益でした。これらの方々に合わせて厚く感謝いたします。

\section{文献}

星野一男, 1984, 応力場, 活断層と南部フォッサマグナのネオテクトニクス, 第四紀研究, 23, 117128.

今永 勇 ・ 松島義章 - 平田大二, 1982 , 相模湾西岸地域の地質地殼変動, 昭和 56 年度環境部会共同研 究報告書, No. 5, 25-36.

井元政二郎 - 唐鎌郁夫 - 松浦律子 - 山崎文人 - 吉田明夫 - 石橋克彦, 1981, 1980 年伊豆半島東方沖群 発地震活動の発震機構, 地震 $2,34,481-493$.

石橋克彦, 1977, 「西相模湾地震」の可能性と東海地震 との関連, 地震予知連絡会東海部会資料, 5368.

IsHIDA, M., 1984, Spatial-Temporal Variation of Seismicity and Spectrum of the 1980 Earthquake Swarm near the Izu Peninsula, Japan, Bull. Seism. Soc. Amer., 74, 199-221.

海上保安庁水路部, 1978, 相模灘付近の地磁気全磁力分布, 地震予知連絡会会報, 20, 41-42.

狩野謙一・上杉 陽・伊藤谷生・千葉達朗・米澤 宏・染野 誠, 1984, 丹沢南部・大磯丘陵周辺飞 打梳る中期更新世以降の断層運動, 第四紀研究, 23, 137-143.

熊木洋太・市川清次, 1982, 大磯丘陵南縁部の中村原面・前川面の変位について, 国土地理院時報,

$\mathbf{5 5}, 24-28$.

久野 久，1962，旧丹那トンネルと新丹那トンネル，科学，32. 397-401.

牧 正, 1983 , 関東地方に拈ける浅発地震の活動様式— $139^{\circ}$ 線活動域—, 地震学会講演予稿集, No. $1,16$.

松田時彦，1977，相模トラフで起こる大地震の発生頻度，地震予知連絡会東海部会資料， 15-24.

松島義章, 1982, 相模湾北岸, 足柄平野にお打る沖積層の ${ }^{14} \mathrm{C}$ 年代とそれに関連する問題, 第四紀研 究, 20, 1-9.

MoGI, K., 1963, Some Discussions on Aftershocks, Foreshocks and Earthquake Swarms-the Fracture of a Semi-Infinite Body Caused by an Inner Stress Origin and Its Relation to the Earthquake Phenomena (Third Paper), Bull. Earthq. Res. Inst., 41, 615-658.

茂木清夫, 1977, 伊豆・東海地域の最近の地殻活動の一解䣋, 地震研究所菓報, 52, 315-331.

MoGI, K., 1979, Two Kinds of Seismic Gaps, Pageoph, 117, 1172-1186.

茂木清夫, 1981 , 東北日本西岸沖一フォッサ・マグナ一東海・伊豆の活動帯と近年の伊豆地方に おける地震活動について, 地震研究所䱊報, 56, 691-711.

中野佳昭・杉田 理・井口博夫・小林洋二, 1980 , 岩脈群からみた伊豆半島のテクトニクス, 月刊地 球, $2,103-109$.

太田陽子・松田時彦・池田安隆・渡辺憲司・D. N. WilliaMS，小池敏夫・見上敬三，1981，三浦半島 および国府津・松田地域の活断層に関する調査結果の概要, 神奈川県委託調査, 1-25.

力武常次, 1980, 前震の震央は本震の震央めざして移動するか?, 地震学会講演予稿集, No. 2, 78.

SEGAWA, M. R., 1983, Detailed Study of the Earthquake Sequence in 1980 off the East Coast of the Izu Peninsula, Japan, J. Phys. Earth, 31, 65-101, 1983.

田中康裕, 1984, 三宅島噴火と周辺の地震活動, 月刊地球, 6, 732-737.

宇佐美龍夫，1980，首都及びその周辺の地震予知，地震予知連絡会地域部会報告， 2，7-14. 
宇津徳治, 1979,1885 年 1925 年の日本の地震活動— $M 6$ 以上の地震 一, 地震研究所罺報, $\mathbf{5 4}, 253-308$.

宇津徳治, 1981, 関東・中部地方拈よびその周辺の地震活動 (1904 年 1925 年), 地震研究所彙報, 56, $111-137$.

Utsu, T., 1981, Seismicity of the Izu Peninsula and Its Vicinity from 1901 through 1980 with Some Remarks on the Characteristics of Foreshock Activities, Bull. Earthq. Res. Inst., 41, 615-658,

山川宜男・吉田明夫・岸尾政弘, $1979, 「 1978$ 年伊豆大島近海の地震」の前震・余震の時空間分布— 伊豆半島周辺域のテクトニクスに関連させて一, 地震 $2,32,89-101$.

YoshidA, A., 1979, Antidislocation as a Source of Earthquake, Paper Met. Geophys., 31, 7-14. 吉田明夫・藤井陽一郎・今永 勇, 1979 , 伊豆半島周辺域のテクトニクス一一特に北伊豆地震の意義 について—, 地震学会講演予稿集, No. 1, 53.

吉田明夫 ・橋本春次 - 福留篤男, 1980 , 伊豆半島東方沖の群発地震, 地震学会講演予稿集, No. $2,2$. 吉田明夫, 1982, 伊豆半島周辺域の最近の地震活動々その特徵, 地震 $2,25,142-144$.

吉田明夫, 1983, 駿河トラフ西側域の地震活動, 地震 $2,36,111-113$.

吉田明夫・岩田孝化・里村幹夫・志知龍一，1984, 駿河湾西岸における活構造線（帯）存在の可能性, 地震 $2,37,453-464$. 